\title{
À LUZ DA TRAGÉDIA: ÉDIPO E O APOTROPAICO
}

Ordep Serra

A princípio, parece despropositado relacionar com a visão trágica o tipo de construção simbólica de que se trata nestas páginas. A sutileza do pensamento dos tragediógrafos gregos, com sua lucidez superior, pouco ou nada teria a ver com o mundo da magia, das crenças populares. Ora, é a este domínio que a idéia do apotropaico parece remeter sempre.

A suspeita de impertinência talvez se agrave com a menção a Édipo. Não faltará quem estranhe a referência ao infortunado herói em tal contexto. Pois quem fala em "apotropaico" refere-se à imaginada eficácia de recursos mágico-profiláticos, coisa que pressupõe uma possibilidade efetiva de evitar infortúnios, deter maldições, pragas ou feitiços, apartando-os através de algum meio privilegiado: objetos ou procedimentos simbólicos supostamente investidos de um poder extraordinário, de uma força ativa que inibe as potências demoníacas hostis, desvia os golpes dos inimigos, impede o contágio das impurezas, livra do infausto. Quando se fala em apotropaico, alude-se, pois, a defesas imaginadas eficazes, apoiadas em qualquer coisa de intangível, mas aptas a protegerem (do sinistro, do nefando). Ora, na história de Édipo, não se faz referência a artes mágicas, talismãs ou feitiços. Na tragédia, particularmente, Édipo está longe de apresentar-se munido de poderes especiais que o protejam. Carece de salvaguardas, de qualquer condão. Indefeso, é presa do nefasto; descobre-se "o mais infeliz dos homens", vítima de um agouro inelutável.

Em uma passagem famosa do drama Rei Édipo, de Sófocles (no seu segundo episódio), quando o herói já suspeita que é o assassino de Laio que é ele mesmo, pois, o criminoso a quem impôs o exílio - sentindo-se impedido também de rever Pólibo e Mérope (seus pais, segundo imagina) por causa do receio do oráculo apolíneo, ele antecipa um lamento de uma forma condicional, muito expressiva: "se for assim [...] quem mais 
infeliz?"... As desgraças temidas, supõe, viriam de um daímon cruel. Ou seja: se for como parece, um poder demoníaco em seu destino (na verdade, idêntico a seu destino) o infelicita.

É o que já imagina o rei apavorado ${ }^{1}$.

E está certo! Desde o começo, impende sobre sua cabeça um agouro inelutável. Quando o herói tenta esquivá-lo, sua tentativa o põe no caminho da desgraça temida: a fuga leva-o a fazer e a sofrer o mal de que foge. Assim se manifesta o daímon irresistível, que termina por apossarse realmente de Édipo, tornado furioso por seu arrebato revelador ${ }^{2}$.

Isso parece bastante para situar o filho de Laio no pólo oposto ao do valor apotropaico.

Há mais, porém. Este herói não apenas sofre de modo inapelável a desgraça de que foge, não só é impelido para ela por seu próprio esforço de evitá-la, como também a provoca.

Voltemos à passagem acima lembrada. Édipo acaba de contar a Jocasta o conflito em que se envolveu na encruzilhada entre Delfos e Dáulis, onde deu morte ao viajante desconhecido. Ocorre-lhe, então, a terrível hipótese: pode ter sido ele mesmo o matador do rei a quem sucede... E se isso for verdade, em toda Tebas, nem cidadão nem estrangeiro o poderá receber em casa, ou sequer falar-lhe: antes, terá de expulsá-lo.

\section{[...] E não foi outro}

Mas eu mesmo quem estas pragas me atirei! (Oed. Rex, vv.819-20)

Édipo reporta-se assim à proclamação que fizera (no primeiro episódio da tragédia), ao abrir o inquérito sobre o assassinato de Laio, com base nos poderes sagrados do seu cargo e de acordo com a praxe jurídico-religiosa adequada: instando os cidadãos a dizerem o que soubessem do assunto, intimou-os a denunciar o criminoso e pronunciou contra este uma verdadeira excomunhão da pólis. Lançou ainda contra o réu desconhecido (e quem ousasse protegê-lo) uma ará, uma terrível maldição (Oed. Rex., vv.246-248). Tão grande é o temor de sua ará que o coro se acha obrigado a responder com uma fórmula ritual, protestando inocência ${ }^{3}$.

Mas a vítima de Édipo será Édipo.

Resumindo: este herói sofre uma desgraça que não consegue evitar, expõe-se a seu impacto quando busca fugir-lhe e provoca, chama para si o próprio mal. A infelicidade que o persegue está nele, com ele se identifica. Tanto que Édipo devém seu próprio perseguidor: ele mesmo se dá caça, acusa-se e denuncia-se, encontra-se e condena-se, agride-se e ferese. Édipo não é autókheir apenas ao golpear-se os olhos (cf. Oed. Rex, 
vv.1331-1332): o incesto em que profana a mãe (e o pai) e o assassinato de seu próprio genitor constituem atos de violência que o atingem, que recaem sobre ele mesmo ${ }^{4}$.

Ora, recorde-se mais uma vez: quem fala em apotropaico fala de um poder defensivo, de algo que protege e põe a salvo o sujeito, que afasta a impureza mortífera. Nada mais oposto a isso que a desgraça dos males autoinfligidos, authaíretoi. De resto, Édipo acaba descobrindo que ele mesmo é a impureza, é (o motivo d)a peste que dizima seus concidadãos. Por sua boca ele o declara, sem dar-se conta do que diz, no início da proclamação de seu édito aos tebanos:

Vocês rezam, e eu, a escutar-lhes o rogo,

Digo-lhes que me acatem e obedeçam à peste! (Oed. Rex,vv.216-217)

Em suma, parece inegável que a figura trágica desse herói está em plena contradição com o valor simbólico, mágico-religioso aqui evocado: sua imagem recorta-se em um espaço que se afigura simétrico ao campo do apotropaico, de acordo com sua definição usual. Mas aí está: tanta contradição, no discurso ambíguo da tragédia, já constitui indício claro da pertinência aparentemente negada.

Dá-se ainda outra coisa: até aqui, falei do apotropaico em termos do discurso dos antropólogos, sociólogos, historiadores, pesquisadores de temas religiosos. Por estranho que pareça, esta é uma limitação a superar. No vocabulário dos estudiosos que incorporaram a referida palavra ao repertório de línguas modernas, seu alcance semântico está definido com uma clareza que não reflete a estrutura semântica do étimo. Para a compreensão adequada do problema, é preciso reconstruir essa complexa estrutura.

O termo não é de uso corrente; mas se falo em "apotropaico" em um meio culto, entre especialistas no estudo de religiões, todos entendem que me refiro a recursos simbólicos empregados com uma intenção profilática, defensiva, em vista de apartar a má sorte, a impureza, o feitiço, as forças demoníacas, a inveja, o "olho ruim". Apotropaico é o que defende dessas coisas, "afasta o mal".

O discurso dos estudiosos procura a precisão, evita o ambíguo. A terminologia de que se vale é artificial; com freqüência, apropria-se de palavras já existentes e as recorta de um modo caprichoso, alterando a tradição. Muitas vezes, o resultado é positivo; pode ser frutífero mesmo em instâncias nas quais a modificação se verifica radical (pensemos, por exemplo, na rica violência com que Platão transformou o sentido de idéia). Neste caso, porém, o procedimento resultou em uma simplificação. 
Em grego, o termo apotrópaios refere-se ao que aparta o mal, ao ente tutelar; mas também qualifica o que provoca horror e repulsa. Da mesma maneira, apótropos é um qualificativo dado a quem se afasta dos homens, da sociedade - e ainda ao que se evita por horrendo, monstruoso, abominável. Designa ainda o ente protetor, aquele que afasta a desgraça.

Ora, essa adjetivação aplica-se perfeitamente a Édipo, com todas as conotações que encerra, isto é, em todos os sentidos opostos que têm os referidos qualificativos. O herói régio é chamado de salvador ao receber as súplicas dos tebanos, que recordam sua grande façanha: livrou de um duro tributo (de vidas humanas) a cidade de Cadmo (Oed. Rex, vv.35-45). Mesmo depois de sua queda, os gratos concidadãos não esquecem que ele, derrotando "a virgem dos versos-adivinhas" fez-se, na sua urbe, "um baluarte contra a morte" (Oed. Rex, v.1200). Isso é bem verdade... Mas lembre-se a reação do mesmo coro, quando irrompe do palácio o triste rei de olhos ensangüentados:

\section{Ó desgraça horrorosa para a vista dos homens! \\ Ó horror mais horrível de todos os que eu \\ Jamais vi! [...] (Oed. Rex, vv.1197-1198)}

Do mesmo jeito, o coro de Édipo em Colono manifesta pavoroso assombro quando o herói lhe aparece e lhe fala pela primeira vez, surgindo do bosque sagrado das Eumênides: embora ignorem ainda quem é esse personagem, os anciãos de Colono fremem de horror só de o contemplar e ouvir (Oed. Col., vv.140-141). No entanto, ele vai levar-lhes proteção.

Em suma, Édipo é um salvador, um protetor - e também, ao mesmo tempo, um ser que horroriza, assombra, provoca repulsa. Em uma palavra: apotrópaios. Ou apótropos.

Na primeira tragédia sofocleana que o filho de Laio protagoniza, ao conhecer quem é e ao dar-se conta de seus crimes, o infeliz pede para ser mandado embora: deseja apartar-se de todos, terminar seus dias isolado no Citerão (Oed. Rex., vv.1451-1454). Nos relatos trágicos (na maioria das versões do mito $)^{5}$, este herói vê-se banido: torna-se um mendigo vagabundo, à margem da sociedade dos homens, que o repelem.

A repulsa é constante. Na última tragédia sofocleana, a reação inicial dos coloniatas, quando Édipo se identifica, é mandá-lo embora (Oed. Col., v.226). Mas assim como ele salvara os tebanos (ao eliminar a Esfinge), Édipo há de proteger os atenienses. Irá defendê-los das armas de Tebas... depois de morto.

O estranho que vive à margem da sociedade, ápolis, é um protetor da pólis. 
Semelhantes contradições, ambivalências e viragens ${ }^{6}$ foram assinaladas por muitos estudiosos do mito do labdácida. Vernant (1981:100-131) o fez em um artigo famoso, em que focalizou o drama Rei Édipo. Evocando as análises de Stanford, Kamerbeek, Knox e outros, o helenista francês apontou a anfibologia que marca tanto a linguagem como a construção desta peça: destacou a estrutura enigmática da obra, acusando a estranha feição do herói-enigma (que se descobre a si mesmo no centro de um enigma) e a profunda contradição que adere aos seus atos, como a definir-lhe a essência o sentido de suas ações sempre se inverte, malgrado seu ${ }^{7}$. O herói é um soberano compenetrado de seus deveres, cheio de zelo por sua pólis - mas, ao empenhar-se em garantir-lhe a segurança, devém ápolis; surge assentado em um trono, tratado como homem poderoso... e revela-se impotente. Tornado o mais impuro dos seres, reveste-se, depois, de um caráter sagrado. A tragédia lhe confere uma posição insólita:

[...] acima e abaixo do humano, herói mais poderoso do que o homem, igual ao deus e, ao mesmo tempo, besta bruta, repelida para o ermo selvagem das montanhas (Vernant 1981:26-27).

Não é difícil multiplicar essas antíteses, evocando a peripécia do rejeitado/entronizado, primeiro suplicado, depois suplicante, do homem de visão que se faz (e se revela) cego.

Em O. T. há um momento em que Édipo se imagina filho da Fortuna (Týkhe; cf. Oed. Rex., v.1080) e pouco depois o coro - no terceiro estásimo da tragédia - pergunta-se, exaltado, que deus o terá gerado no Citerão. Terrível engano: o herói é vítima da Týkhe, um desgraçado que os deuses aborrecem.

Sua figura apresenta uma concentração de signos opostos. Ele é um salvador e um maldito. Atrai inveja (cf. Oed. Rex., vv.1525-1527) e provoca repulsa. Move-se para onde está, no seu inquérito. Superpõe-se a si mesmo, em uma espantosa saturação sincrônica. O incesto constitui esta disforme violação da temporalidade. Só no termo de sua catástrofe Édipo é "encontrado pelo Tempo" (Oed. Rex, v.1214).

No plano da diacronia, sua trajetória configura uma série de tropaí: Édipo nasce dos soberanos, de que seria, portanto, o legítimo continuador - mas com a sina de descontinuar, isto é, de romper a união deles, cortar-lhes a vida. É, por isso, enjeitado e exposto à morte, colocado à margem da sociedade, em meio bestial; mas em seguida vem a ser salvo e se vê adotado por soberanos: adquire, pois, o status de possível sucessor de um rei. Assim, procedendo da periferia selvagem, ruma ao centro de uma 
pólis, invertendo o primeiro movimento de seu destino. Mais tarde, contestado por um homem bêbado, deixa a cidade a que se havia integrado para levar sua questão ao deus lúcido. Este lhe dá uma resposta em desencontro aparente com a pergunta. A fim de fugir do predito, Édipo bane-se da urbe que julga sua (fica de novo ápolis); desvia-se, troca de rumo para não se encontrar com os pais nem fazer-lhes mal. Em seguida - e por isso mesmo - encontra o pai e o elimina. Adiante, ainda empenhado em desviar-se dos (supostos) genitores, confronta-se com um ser bestial que lhe propõe uma pergunta obscura; responde a ela com clareza. Em conseqüência, volve da periferia para o centro da sociedade, sendo então entronizado (como týrannos, não como herdeiro legítimo) na pólis onde se julga estrangeiro. Mas com isso desposa a própria mãe, de forma bestial e "às cegas", isto é, sem sabê-lo. De decifrador, passa então a enigma. "Decifrado" (por Tirésias) não vê que o foi; quando o vê, cega-se. No que chega a Tebas, aparta a morte da urbe; quando se instala em seu centro, atrai a morte (a peste) que dizima os concidadãos. Buscando purificar a cidade, revela-se impuro e fonte de impureza; então bane-se de novo, ou de novo é banido por sua gente - que mais tarde tenta trazê-lo de volta à sua pólis.

No termo, o herói banido e buscado há de incorporar-se a uma cidade estrangeira, que defenderá contra os seus.

Destacarei algumas dessas contradições que se relacionam com a movimentação de Édipo entre cidades.

Considere-se o esquema abaixo:

I

II

III

I
1

A

B

2

$$
\begin{array}{ll}
\text { condenado } & \text { salvo } \\
\text { enjeitado } & \text { adotado } \\
\text { degradado... } & \text { elevado }
\end{array}
$$

3

A

B

$\begin{array}{ll}\text { afastado do trono } & \text { entronizado } \\ \text { chamado para o trono } & \text { destronado }\end{array}$

$\begin{array}{ll}\text { banido } & \text { acolhido } \\ \text { buscado } & \text { guardado } \\ \text { desterrado } & \text { enterrado }\end{array}$


Nesse esquema, A corresponde à "cidade natal de Édipo", e B constitui indicação de "outra cidade". (É claro que o valor de A se mantém o mesmo, enquanto B está por "Corinto" na coluna 2, e na 4 por "Atenas"). A vantagem da simplificação é clara: mostra a forma constante do movimento, isto é, assinala uma polarização que se mantém, embora variando um dos pontos de referência.

O quadro não exige muitas explicações. É fácil reconhecer (I) que Édipo não só foi enjeitado em Tebas e adotado em Corinto (livrando-se da morte a que fora condenado pelos próprios pais), como também, na passagem, sofreu uma degradação (atado pelos pés à maneira de um bicho, em seguida recolhido no mato, que nem uma cria selvagem, e presenteado feito uma coisa) antes de elevar-se a alto posto, subindo aos joelhos de Mérope. Tampouco nos custa recordar que (II), tendo concebido a suspeita quanto à sua origem, ele se afastou de Corinto (por sua própria decisão), abandonando, portanto, a possibilidade de ascender ao trono de Pólibo; mas, no seguimento de suas aventuras, veio a ser entronizado em Tebas. Por outro lado, em Rei Édipo mostra-se o herói, já aflito com a possibilidade de reconhecer-se matador de Laio, recebendo de um mensageiro coríntio o anúncio de que o chamavam ao trono lá no Istmo; porém, o inquérito que então promoveu leva-o a ser destronado em Tebas, de acordo com sua própria decisão.

Já a última tragédia sofocleana conta-nos que (III), banido por sua pólis, o rei cego veio a ser acolhido em Atenas, onde foi Creonte buscá-lo com o intuito de o levar de volta; mas Édipo recusou-se a ir e os atenienses o guardaram, tomando sua defesa.

Resta considerar a última oposição marcada no quadro. Embora o pareça, ela não é repetitiva no que fala em "desterrado". Sucede que uso aí esta palavra com um sentido muito especial, com valor "duplo".

Reporto-me ao Édipo em Colono. Mais precisamente, refiro-me a um trecho (vv. 305-410) do grande diálogo do protagonista com Ismene, que anuncia ao pai as novidades de Tebas: a disputa de Etéocles e Polinices pelo trono, a guerra iminente e os novos oráculos, segundo os quais o sucesso da campanha dependerá de Édipo - será vitorioso quem ele favorecer. Ismene acrescenta que o próprio Creonte está vindo em busca do herói. Este indaga por quê, e sua filha explica: para estabelecê-lo nas proximidades da terra de Cadmo (ankhí gês... kadmeías), porém de modo que ele não pise essa terra. O herói então pergunta que vantagem esperam os tebanos de um (homem) jacente às suas portas (thyrassi keiménou); pressupõe, portanto, que aí ficaria já morto. Ismene confirma: é que caro pagaria quem lhe desrespeitasse a tumba. Por isso o querem os cadmeus 
em sua fronteira (... pélas... khóras) (Oed. Col., vv.404-405): querem-no, compreende-se logo, para servir-lhes de defesa. É quando Édipo indaga se o recobririam com o pó de Tebas e a filha contesta (Oed. Col., v.407): não, pois isso tò émphylon haîma ${ }^{8}$ lhe interdita... Em suma, os tebanos buscam Édipo não para lhe revogar o exílio e instalá-lo de novo em sua pólis, mas para que fique jazendo às portas desta, como proteção. Ou seja: buscam-no, por certo, mas o querem ainda desterrado, em sentido pleno: ele não pisará a terra de Tebas, nem ela o há de cobrir. Como se sabe, os atenienses é que terão o defunto Édipo enterrado em Colono.

Para destacar esses elementos, o esquema traçado mais acima excluiu muitos outros. É preciso reaver alguns aspectos que ficaram elididos.

Salta à vista que se privilegiou o eixo configurado pela cidade de Tebas na análise assim esboçada da movimentação de Édipo: ela é a referência que dá sentido à posição de "outra cidade" como um pólo contraposto. Mas é preciso ir além dessa primeira aproximação. Ora, basta refletir um pouco para ver que os contrastes marcados no centro do quadro (campo II), entre a segunda e a terceira coluna, indicam mudanças que não implicam de forma imediata e necessária a oposição entre atos cumpridos nos lugares a que se referem os indicadores B e A. Édipo não foi afastado (nem se afastou) do trono coríntio em Corinto. Ele saiu de lá para saber de seu destino em Delfos; só depois de ouvir o oráculo da Pítia decidiu não voltar mais à pólis que julgava ser sua cidade natal. Uma conseqüência disso é que ele, em tese, abandonou a possibilidade muito concreta de suceder a Pólibo. Estando em Tebas - já afastado, conforme julgava e pretendia, do trono de Corinto foi Édipo entronizado na urbe que salvara. Do mesmo modo, em Tebas ele foi chamado para o trono coríntio, mas pouco depois viu-se destronado (sempre em Tebas) por obra de sua terrível descoberta e de sua própria determinação; perdeu o trono desta última cidade... Assim, embora os registros da segunda coluna, nesse campo II, digam respeito ao trono de Corinto, a ação correspondente não se localiza aí.

De qualquer modo, a indicação é válida: trata-se simplesmente de apontar os extremos significativos que dão sentido ao movimento contrapolar do herói.

Feita essa observação, torna-se mais fácil ver que nos extremos do quadro os contrastes implicam deslocamentos efetivos, assinalam passagens. Caso se queira uma descrição mais completa e precisa dessas passagens, será imprescindível a indicação de um espaço intermediário haverá que assinalar as fronteiras em que tudo se decide.

No Citerão, entre Tebas e Corinto, Édipo deixa a condição de vítima de uma morte certa e logra o resgate, a salvação, quando um coríntio o 
toma nos braços e decide levá-lo a seu rei. Nessa zona intermediária, completa-se a degradação e inicia-se a elevação da criança fatídica. Por outro lado, é em uma fronteira que Édipo vem a ser efetivamente acolhido e guardado pelos atenienses.

O esquema simplificador permite chamar a atenção para um dado fundamental. A vida de Édipo transcorre, em seus momentos decisivos, entre cidades a que ele pertence e não pertence.

Em Corinto, ele é considerado filho do soberano. Candidato natural ao trono, tem um lugar de destaque entre os cidadãos. Mas uma boca obscura lá mesmo denuncia sua origem incerta, coloca sob suspeita sua condição privilegiada e sua cidadania. A suspeita é forte o bastante para encravar-se no íntimo do herói e o levar muito longe, ao santuário fatídico, em busca de resposta para sua inquietação. De resto, como ele mesmo descobrirá, Édipo realmente não é coríntio de nascimento. Por outro lado, em Tebas, onde ele chega na condição de estrangeiro, o príncipe vagabundo ascende ao trono crendo que não é nativo. Quando se descobre nativo, tem de exilar-se. Em Atenas, por fim, o pobre recebe acolhida e obtém a moradia final; mas não devém polítes ${ }^{9}$. A rigor, portanto, em nenhuma cidade esse herói tem uma radicação efetiva. Filho de Pólibo e Mérope, mas não verdadeiro filho de Pólibo e Mérope, esse coríntio não é de fato coríntio; tirano de Tebas, esse super-cidadão dos cadmeus reina enquanto não se pode dizer tebano por nascimento: quando se revela nativo, perde reino e cidadania; herói de Atenas, seu guardião e protetor, radicado no demo de Colono, onde tem o túmulo, Édipo não é, nem fica sendo, ateniense ${ }^{10}$. Enfim, ele preserva sempre algo de estrangeiro no mundo da cidade. Isso faz parte de sua estranheza.

Entende-se que acabe estabelecido (de um modo vago) em uma fronteira.

A trajetória toda do triste herói pode descrever-se como uma oscilação entre centro e margem.

Mas ainda é preciso reintegrar alguns dados que a abstração do esquema deixou de parte. (O propósito desse abandono provisório foi cumprido: agora será possível apreciá-los melhor). Mesmo um leitor muito desatento nota logo uma coisa: no quadro acima, ignorei alguns lances capitais da trajetória de Édipo. Creio que já é possível relacioná-los. De certo modo, eles correspondem a experiências vividas em "fronteiras" opostas, entre o humano e o desumano.

Édipo viaja ao umbigo do mundo, onde consulta o deus. O santuário da Pítia representa, sem sombra de dúvida, um lugar de contato entre o humano e o divino; aí o espírito celeste de Apolo comunica-se com os homens.

Na seqüência de suas aventuras, o filho de Laio chega a um ponto, nas cercanias de Tebas, onde tem novo contato com o desumano; só que, 
enquanto no santuário délfico o herói se aproxima do mundo superno, perto da cidadela de Cadmo ele entra em relação com um ser infernal: a Esfinge. Ora, de acordo com um escólio ao verso 1760 de As Fenícias, a Esfinge é khresmológos, ou seja, uma profetiza - como a Pítia - que canta seus "oráculos" (khresmoí). Também na versão de Sófocles, a tremenda cantadora ocupa uma posição oposta e simétrica à de Apolo: o deus soberano dá respostas enigmáticas, a donzela bestial profere enigmas, inquirindo. A adivinha é uma espécie de simétrico do responso oracular, também tortuoso (loxíaco) ${ }^{11}$.

Advertida essa correspondência, descortina-se melhor outro ponto significativo na mesma trajetória. Não é difícil reconhecê-lo, em meio aos dois que foram assinalados logo acima - como todos recordam, depois da consulta a Apolo e antes de deparar a Esfinge, Édipo tem o encontro fatídico com Laio em uma encruzilhada. Pois bem, uma encruzilhada é um nãolugar, uma passagem por definição onde se cortam diferentes lugares sem que aí estejam (embora "apareçam" em figura de compossíveis): um campo virtual no qual as metas se confundem e se tocam, o longínquo envolve-se na proximidade, o contínuo recai no descontínuo. Um não-lugar, em suma, porque saturado - e vazio - de outros. Eis uma terra de ninguém, onde todos são fronteiriços; uma fronteira sem lindes, um ponto em que as direções podem embaraçar-se, o desvio insinua-se, as destinações, ao menos em tese, são suscetíveis de mudança: um zero dos destinos. A própria forma do trívio já se mostra fortemente sugestiva: um caminho truncado na unidade de seu rumo que aí se divide, abre-se à dúvida, em vias a desviar-se. A encruzilhada é ainda espaço de trocas e chave de espaços; nela, um viajante se encontra com outras viagens atravessadas na sua. É foco de interferências, corpo do que corresponde à simultaneidade no espaço; nó de caminhos prestes a romperem-se, onde o trânsito pode ser barrado pelo trânsito. É o cenário por excelência das trocas e dos confrontos, dos desafios de comunicação.

A partir daí, é preciso recomeçar - e ler em nova clave a mesma trajetória.

O que põe em movimento o herói Édipo, o que o faz deslocar-se, é uma comunicação clara, mas truncada, ao mesmo tempo excessiva e insuficiente. Vejamos: de acordo com o relato de Sófocles, um homem bêbado, em uma festa, chamou o príncipe de "filho postiço". A embriaguez é imagem de confusão. Mas também imita o transe inspirado, o furor da bacante: in vino veritas... Ela também manifesta o oculto. No caso, houve um excesso; o bêbado disse o que deveria calar, contou o que era segredo, declarou o que seus reis silenciavam (por isso provocou sua ira). Foi 
impertinente de toda forma, porque "falou demais" e porque disse o que não lhe perguntaram. Mas não se explicou, de modo que Édipo ficou em dúvida. Percebe-se aqui uma falta: se Édipo ficou intrigado, é porque o bêbado também "falou de menos". O dito não era bastante, não era conclusivo, apesar de claro em seu enunciado. Assim, essa contestação gerou uma pergunta. O herói levou-a, primeiro, a seus pais, também envolvidos na questão. Eles simplesmente negaram a afirmativa do bêbado, com quem se mostraram zangados. Édipo ficou satisfeito com sua atitude, mas insatisfeito com sua resposta, tanto que decidiu prosseguir na indagação levando-a adiante: foi consultar o oráculo.

O deus deu-lhe uma resposta em aparente desencontro com a pergunta. No texto sofocleano (Oed. Rex, vv.787-790), o herói interpreta-a como uma não-resposta, seguida de uma informação não solicitada (ele indagara do passado e o deus contestou-o com um anúncio do futuro):

[...] Febo, à minha demanda sem dignar-se responder, despediu-me - porém ao desgraçado de mim, fez predição de horror e lástima

De novo, do ponto de vista de Édipo, dava-se com ele uma comunicação ao mesmo tempo excessiva e insuficiente.

$\mathrm{O}$ "desvio" da resposta com relação à pergunta reflete-se em outro, ou melhor, provoca outro. Isso fica mais visível na versão do Pseudo-Apolodoro (Bibl. III, $5,7)$. De acordo com este relato,

[...] o deus disse-lhe [a Édipo] que não viajasse rumo à pátria, pois [se o fizesse] mataria o pai e se uniria com a mãe. Ouvindo isso, e julgando-se filho dos que se diziam seus pais, o herói desviou-se de Corinto [...]

...E logo em seguida deparou Laio.

O embate na encruzilhada corresponde a um momento em que toda a comunicação se anula. Não há indagação nem resposta. Os golpes as substituem em uma troca desigual. Na versão sofocleana (cf. Oed. Rex., vv.804813), só a violência "fala". Mas os protagonistas desse embate que rompe toda a comunicação "têm em comum a natureza"

Recapitulemos um pouco. Até aqui, a trajetória de Édipo, considerada segundo a nova clave, pode ser resumida como segue: primeiro, uma contestação (exploro o duplo sentido do termo) gera uma pergunta aquela que Édipo faz a Pólibo e Mérope; estes o deixam satisfeito e 
insatisfeito pelo modo como reagem. Depois, o herói consulta o oráculo, cuja resposta parece "desviada" (da pergunta) - e efetivamente o leva a um desvio: para o consulente, ela não corresponde à sua demanda, não a satisfaz; por outro lado, carrega uma mensagem inesperada que excede de forma ominosa o campo da indagação.

$\mathrm{Na}$ encruzilhada, a falta de comunicação traduz-se em excesso violento: ocorre um impasse, em que perguntas e respostas se trocam por golpes. Também cabe dizer que aí o diálogo se anula: ambos os antagonistas da cena bruta se contestam, sem nada indagarem; seu encontro é um desencontro em que eles se batem e se ignoram.

Passo agora a um episódio crucial: o confronto entre Édipo e a Esfinge, tal como ele sucede nas versões mais conhecidas, em particular, nas trágicas.

Vou desde logo fazer referência a uma sua análise por Lévi-Strauss (1976:11-40), que aí centrou uma interpretação do mito de Édipo e descortinou a possibilidade de uma leitura de toda a mitologia com base na oposição, feita a partir desse ponto-chave, entre os "mitos edipianos" e os "percivalianos". Recordo: em um momento decisivo do romance de Percival, o herói, no castelo do rei Amfortas, não se atreve a indagar a quem serve a taça esplêndida que vê deslocar-se sozinha à sua frente; assim, como depois ficará sabendo, ele perde a oportunidade de romper o encantamento que pesava sobre o rei enfermo e a terra gasta. Percival, o casto, não faz uma pergunta; e porque assim descura a resposta disponível, deixa de obter um grande sucesso. Já Édipo, o incestuoso, faz reunir-se uma resposta inesperada com a pergunta enigmática: no seu caso (Lévi-Strauss 1976:31), "a união audaciosa das palavras mascaradas", tal como "a de consangüíneos dissimulados" leva à ruína, "gera o apodrecimento e a fermentação". Provoca a peste tebana. Logo, ainda de acordo com Lévi-Strauss, os mitos edipianos têm a ver com "um inverno sem fim", que o herói revoga ao decifrar o enigma, enquanto o problema a ser resolvido no ciclo do Graal é o do "gaste pays", do verão revogado. O ponto-chave de todas essas correlações está em uma correspondência básica: a castidade (estéril) de Percival está para a "resposta sem pergunta", assim como o incesto (corrupto) de Édipo está para a "pergunta sem resposta" - uma simetria que em outra oportunidade (Lévi-Strauss 1984:129-137) traduziu em termos da oposição entre o problema da "comunicação interrompida" (Percival) versus o problema da "comunicação excessiva" (Édipo).

Mas as considerações feitas acima, nos comentários suplementares ao quadro que esbocei, mostram que o tópico, pelo menos no concernente ao mito de Édipo, é muito mais complexo. Não há como negar que nessa história do herói de Tebas verificam-se desencontros de pergunta e res- 
posta, há comunicação excessiva e insuficiente; que ele passa de maneira contínua de contestado a indagador, de decifrador a enigma, assim como vem a ser, de um modo simultâneo, o inquiridor e o objeto da inquisição. É um longo processo de viragens, que Lévi-Strauss simplificou ao deter-se em um momento.

De resto, talvez não seja tão seguro dizer que Édipo efetivamente resolveu a questão do monstro... Segundo mostrou Vernant (1981:114), ele a decifrou de modo apenas parcial — de um modo que abriu caminho para nova cifra.

Tentarei esclarecê-lo: unindo-se a Jocasta, o herói tornou-se um monstro enigmático, à imagem da Esfinge e, enquanto assassino de Laio, veio a ser ele mesmo uma resposta que aguardava a pergunta.

Vejamos... Quem lê com atenção o Rei Édipo, logo se dá conta de que a peste, desde o princípio, é percebida pelos tebanos (e por seu rei) como uma mensagem cifrada: todos os personagens do drama entendem que ela significa alguma coisa, com a qual não atinam. No que recorrem a seu rei para pedir-lhe providências, os tebanos fundam suas esperanças no fato de ser ele um vitorioso decifrador de enigmas. Mas (como no fim se vê) o que a peste significa é o próprio Édipo.

O deus Apolo indica a resposta no primeiro lance; Tirésias precisa mais a indicação; os depoimentos dos pastores a tornam exata, isto é, trazem à luz a identidade do herói, a chave do enigma. Segundo mostrou Michel Foucault (1971), a tragédia Rei Édipo mostra o reunir-se de fragmentos de resposta até que se completa a decifração - quando se juntam todos os quesitos com as falas esclarecedoras. O que há de mais decisivo na história de Édipo são as constantes tropaí. Vernant em parte iluminou a peripécia do triste rei ao compará-lo com o pharmakós: elevado, depois degradado, posto no centro da pólis e em seguida expulso, ele assim lhe daria remédio, purificando-a. Mas, se é que isto pode aplicar-se à leitura de Oidípous Týrannos, a seqüência mítica explorada por Sófocles na sua última tragédia exige ir adiante.

A função positiva do pharmakós cumpria-se no seu exício ou exílio, no rito que o afastava da cidade, fosse pela morte, fosse pela simples expulsão. Se existem muitas indicações de que essa alternativa (morte/ fuga) ficava aberta, não há indício de que o homo piacularis, uma vez banido, viesse a ser ainda buscado, conforme aconteceu com Édipo. Os tebanos o procuraram depois de o haverem expulso, a fim de transformálo em um apotropaico, uma defesa erigida em sua fronteira contra os inimigos. No entanto, em uma última e radical viragem, Édipo veio a tornar-se um apotropaico contra os seus, na fronteira dos inimigos. 
Mesmo não se considerando a variante coloniata do mito, caso se levem em conta outros desenvolvimentos da saga dos labdácidas, logo se vê que Édipo não figura como um simples pára-raios da praga, ou um veículo da desgraça, que a transportaria consigo para longe da terra de onde foi expulso. Saturado de maldição, ele se investe do poder de amaldiçoar e sua praga tem garantida eficácia... contra os seus.

Em defesa de outros.

É o que mostra também o Édipo em Colono. Mas isto não se verifica apenas na derradeira tragédia de Sófocles. O tema remonta à antiga epopéia Thebaida, como mostram fragmentos remanescentes.

Pode-se ainda considerar um testemunho épico tardio: a famosa passagem do Canto I da Thebaida de Estácio (vv.46-87) onde se mostra o herói horrendo a pronunciar sua imprecação, origem de uma guerra fratricida e de inúmeras desgraças para a Cidade das Sete Portas. O poeta lembra (vv.4648) que Édipo já exercera uma vingança terrível contra si mesmo, furando os próprios olhos - e logo o revela "infernalizado" em sua vida tenebrosa. A descrição que se segue (vv.49-55) autoriza esse neologismo: mostra o herói, no recesso de sua morada, envolto em trevas, com os penates invisíveis ao dia. Está coberto pela escuridão da morte, embora o sobrevoe "a luz cruel de seu espírito". Nesse lugar tenebroso, as Fúrias de seus crimes o assaltam. O tremendo rei volta para o céu as órbitas vazias, golpeia a terra maldizendo e pronuncia sinistro discurso (vv.56-87), no qual se dirige de um modo "familiar" aos deuses que regem o Tártaro. Conclama o Estige dizendo que o vê e invoca Tisífone de maneira quase filial: alega méritos junto à Fúria (v.60), responsabiliza-a por todos os sucessos de sua vida (cf. v.66), diz que para ela gerou os filhos e deixou os próprios olhos (caídos) no regaço da mãe. Finalmente, alegando o desprezo dos filhos, faz seu rogo: pede a Tisífone que irrompa entre os desgraçados a cortar-lhes os laços de parentesco.

Em suma, esse Édipo é um monstro infernal.

Pois bem: o horror de um monstro dos infernos também o qualifica para servir de apotropaico. Basta lembrar o exemplo da Górgona no escudo de Atena - e de sua imagem em numerosos escudos humanos.

Também relaciona Édipo com o domínio do apotropaico o elemento de fascinação que se acha em sua gesta.

No horizonte religioso - na perspectiva dos antigos gregos e romanos quem diz "fascinação" diz, ao mesmo tempo, atração e repulsa. Édipo cego, com os olhos vasados, é um espetáculo medonho que não se quer contemplar.. mas ninguém consegue evitá-lo.

Não é apenas isso o que o liga ao campo do fascínio. Este campo constitui-se como um espaço mágico onde o poder dos olhos e o do sexo 
se associam de forma ambivalente. De acordo com o famoso Lexicon Totius Latinitatis de Forcellini (s.v.), fascinum, em grego baskanía, constitui um tipo de encantação por obra da qual ficam os homens enleados, perdem seu livre arbítrio e o governo de sua própria mente. Em uma segunda acepção, esclarece o dicionarista, o termo fascinum empregava-se para designar o falo, porque (explica ele) os antigos usavam [imagens d]o falo como defesa contra o enfeitiçamento: era crença que esta imagem repeliria o olho ruim da inveja ${ }^{13}$.

De acordo com Boisacq (1923), fascinum, empréstimo feito ao grego báskanos (que, por sua vez, teria um étimo ilírio ou trácio), foi modificado pela influência de fari, de fateri e de cano. Na língua grega, báskanos designa o feiticeiro; o seu cognato baskánion corresponde a "amuleto" (cf. Aristoph. Ranae 592). O sentido básico do verbo correspondente, baskaíno, é "enfeitiçar por meio de mau olhado"; já o abstrato baskanía muitas vezes pode ser traduzido por "inveja".

Com o termo "fascinação", cabe indicar um enleio (mágico: "homines ita ligantur ut liberi non sint, nec mentis compotes"). A etimologia autoriza-me ainda a que pense na ambivalência de poderes associados aos olhos e ao sexo; e as "contaminações" apontadas por Boisacq indicam que este termo também é capaz de conotar a magia da palavra, a do canto em especial.

Ora, antes de tornar-se um monstro, Édipo celebrizou-se por confrontar um monstro: a Esfinge cantadora que deixava suas vítimas enleadas. Em grande número de representações plásticas dos ataques da Esfinge aos tebanos e do confronto decisivo entre o herói errante e a "cadela rapsoda", mostra-se um "duelo" sem armas: uma disputa de palavras e um desafio de olhares.

Na pintura de uma taça hoje do Louvre (G 266), de cerca de 480 a.C., em figuras vermelhas, obra de Mácron, vêem-se os tebanos representados por homens de diferentes faixas etárias. A Esfinge, de pequenas proporções, de bote armado no topo de uma coluna, projeta-se para a esquerda, quase a precipitar-se sobre um jovem sentado, envolto em um manto. Ele volta para a fera a cabeça, com ar de assombro. Atrás e à esquerda desta vítima indefesa, um jovem começa a correr, com um braço erguido e uma expressão de espanto. Atrás do monstro, um homem adulto, sentado de costas para a cena sinistra, volta os olhos a fim de contemplála; adiante, um moço de pé, com ar de espanto, olha na mesma direção. Este conjunto acha-se flanqueado pelas alças da taça. Girando-a, contempla-se um outro quadro, complemento do primeiro, com quatro personagens a correr, em atitudes que revelam pânico e sugerem a troca de 
mensagens perplexas, carregadas de sobressalto. Mais à esquerda, um jovem e um adulto tomam a mesma direção, o segundo de cabeça voltada para trás; adiante deste, do centro para a direita, um outro varão (barbudo, careca, visivelmente mais velho) corre no mesmo rumo; e um quarto personagem, um homem robusto, vem vindo ao seu encontro. No primeiro "quadro" (no lado que descrevi primeiro), o homem sentado seria um paidagogós, cujos pupilos o monstro ameaça; no segundo, "os tebanos, esquecidos das conveniências, correm em todas as direções, espalhando por toda a vila o último mal-feito do monstro" (Moret 1984:31). Mácron parece ter querido acentuar um elemento da narrativa pintada: a interpelação da Esfinge e o rumor que ela provoca, o pânico que suscita ao espalhar-se a notícia de seus ataques. Mas por outro lado ele mostra muito bem outra coisa: o enleio mortal do jovem que a Esfinge assalta.

Considere-se agora um ésquifo em figuras negras do Pintor de Teseu, obra pouco anterior, datável de 490/80 a.C. (Museu de Atenas, 18.720). De um lado, vê-se a Esfinge sobre uma coluna, asas na vertical, ancas mais elevadas que o peito, uma garra a projetar-se para baixo, olhos fitos em um jovem todo encolhido em seu manto, sentado em uma pedra; atrás dele, um cavaleiro nu assiste, à altura de cuja nuca, mais atrás, vê-se a figura imprecisa do que seria um pássaro, ou quiçá uma ave-falo (Moret 1984:42). Por trás da Esfinge, um bode mira com espanto. Do outro lado, vê-se quase a mesma cena, com algumas diferenças: as testemunhas por trás do jovem são um homem e uma mulher; já a atitude da Esfinge é ainda mais agressiva: ela está quase saltando sobre sua vítima, rumo à cabeça em que projeta a sua, como se quisesse penetrá-la com os olhos. A aparência do rapaz é inteiramente fúnebre. Quem está acostumado a contemplar as obras de arte cemiteriais dos gregos antigos reconhecerá no infeliz uma "pose de morto". O que ele tem de ainda vivo são os olhos arregalados, por onde o estupor da morte o penetra, segundo o artista dá a enten$\operatorname{der}^{14}$.

Evocarei brevemente alguns documentos que mostram o confronto da Esfinge com o herói.

O diálogo vertido no registro visual dos olhos que se confrontam é o elemento básico da cena representada pelo Pintor de Édipo na famosa taça do Vaticano r. 16. 541 (figuras vermelhas, circa 470 a.C.), muito embora nela também se percebam vestígios de uma inscrição onde se reproduzia a fala da esfinge [Robert 1915:51; Moret 1984 cat. 87; Krauskopf 1981 (LIMC s.v. Oidipous) kat. 19, pl. 50].

Este elemento do duelo visual prevalece também na conhecidíssima cratera em cálice de Lecce (r. 610), em figuras vermelhas, mais ou menos 
da mesma data (CVA 1, 8/3, PL. 10/1-2. Moret 1984., cat. 69 73, pl. 39/23), assim como na pintura de um lécito de fundo branco de Tarento (4566), de cerca de 450 a.C., atribuído ao Pintor de Lupoli (Moret 1984. cat. 73 pl. 42/3-5; Simon 1981:29, pl.7) e na cratera de Brunswick (Maine, Bowdoin College 1913.8), pintada em figuras vermelhas (Moret 1984, cat. 76, pl. 44.), circa $440 \ldots$ etc. etc. O motivo consagrou-se, teve ampla difusão no espaço e no tempo.

Um vaso que pertence a uma coleção privada, na Alemanha, uma pélike em figuras vermelhas, do Pintor da Centauromaquia do Louvre, obra de 440/430 (Moret 1984. cat. 82 pl. 47), mostra um momento de interrupção do confronto visual: Édipo, de cabeça levemente inclinada, medita sobre o enigma... e a Esfinge parece procurar-lhe os olhos. Já em outra pélike (também em figuras vermelhas), obra talvez de 440, do Pintor de Aquiles, guardada agora no Museu de Berlin (F 2355; cf. Moret 1984. cat. 79, pl. 46), registra-se o momento final em que esse confronto se encerra, no termo do diálogo-desafio: a feroz parthénos, sobre um rochedo, tem a cabeça baixa, como a mirar o precipício onde vai atirar-se, enquanto Édipo a contempla com um olhar sereno ${ }^{15}$.

Uma coisa logo é notada ao se compararem as representações existentes na pintura cerâmica helena dos ataques da esfinge aos tebanos com as do seu confronto com Édipo: ao contrário dos tebanos em sobressalto, Édipo sempre se mostra sereno, mira a esfinge sem perturbação. As vítimas do monstro são mostradas mortalmente envolvidas, paralisadas, tolhidas, enleadas pelo seu olhar feroz. Elas recebem a mirada da parthénos de modo passivo, são manifestamente incapazes de resistirlhe. Já Édipo sustenta com limpidez o olhar da inquisidora e até quando é mostrado a meditar desviando um pouco a vista, fica evidente que não sofre o enleio fatal.

Nos testemunhos literários do mito de que ela é uma personagem destacada, a Esfinge "encanta" no sentido primitivo do termo, enunciando seu carme-desafio. Na iconografia, o "encanto" traduz-se em mirada por injunção do meio, certamente, mas de modo que revela outro aspecto do mesmo poder: nessas representações, a esfinge parece que, ao pé da letra, inocula a morte em suas vítimas (entenda-se "inocula" no sentido etimológico do termo). Assim, através dos olhos, o monstro enleia os tebanos, como se os hipnotizasse.

Creio que até aqui não suscitará muitas discussões o modo como assinalei os "elementos de fascinação" presentes na história da proeza de Édipo. Mas fascinação, de acordo com o que especifiquei, envolve ainda um sentido sexual. É mesmo possível encontrá-lo, nesse caso? 
Já fez furor a tese delcourtiana da Esfinge "íncuba". Jean-Marc Moret contestou-a com vigor. Tomei posição sobre o assunto em outro ensaio (Serra 1997), acompanhando Moret. Evocarei apenas alguns pontos do debate. Delcourt interpretou como representações de perseguição erótica cenas em que uma esfinge corre atrás de grupos de moços ${ }^{16}$ e como um embate amoroso cenas em que se vê um homem jovem sob uma esfinge - v.g. em uma série de lécitos fúnebres, áticos, que ela cita (quatro do Pintor de Hémon, dois do pintor do Empórion) ${ }^{17}$. Os documentos dessa série que se devem ao Pintor de Hémon têm um mesmo esquema de composição. Em todos eles, acha-se desenhado um homem jovem sob uma esfinge, flanqueados os dois por outros personagens. Não me parece haver evidência de que, nas pinturas descritas, a esfinge e sua presa estariam copulando em presença de testemunhas horrorizadas. Francamente, não acho que o Pintor de Hémon buscasse representar um coito, mesmo bestial, de forma tão inverossímil como a que seria tentada nesses casos, de acordo com a hipótese delcourtiana. Nos vasos onde sua imagem é mais visível, o rapaz envolvido olha para o chão, onde um de seus braços descai; ele pende de um lado, mostra-se meio torto com relação ao corpo da fera, cujo ventre não toca o seu, embora ele ainda lhe cinja os flancos com as pernas. Será essa uma atitude física não digo apropriada para, mas ao menos compatível com o desempenho de um amante no curso de um ato sexual? De resto, há um problema anatômico: na posição em que esse efebo se prendeu à Esfinge, nos desenhos em apreço, só poderia copular com a terrível parceira se esta tivesse a vulva em uma parte do corpo onde nenhuma leoa ou cadela jamais a teve ${ }^{18}$.

A objeção que levanto contra a leitura delcourtiana dessas representações talvez seja considerada impertinente, porque implica uma apreciação realista da anatomia de um ente fabuloso. Mas o difícil é provar que ao conceberem animais fabulosos os artistas plásticos gregos despojavam-se de qualquer preocupação de verossimilhança anatômica. Podese mostrar com provas abundantes que, pelo contrário, quando figuravam centauros, eles os faziam muito verossimilmente eqüinos na parte eqüina do corpo e bem humanos no elemento humano.

Reporto-me aqui à tese de Delcourt por bons motivos: ela alcançou grande prestígio, foi aceita em amplos círculos, convenceu muita gente. Serviu de base, por exemplo, à famosa interpretação "americana" do mito de Édipo proposta por Lévi-Strauss (1967:cap.XI), que não a teria formulado sem tal apoio, isto é, se não estivesse convencido de que a esfinge tebana era um personagem do mesmo tipo mítico da old hag dos Pueblo. 
Psicanalistas também consagraram de forma dogmática a leitura de Delcourt deste aspecto do mito que mais os interessava. André Green (1994:92, nota 1) tirou daí conclusões extraordinárias: segundo ele, se Édipo não tivesse decifrado o enigma, morreria antes do amanhecer, obrigado que seria pela Esfinge a copular com ela a noite toda!

Entre os helenistas, autoridades respeitáveis continuam a defender a caracterização delcourtiana da Esfinge: bastem os exemplos ilustres de Marcel Detienne e Emily Vermeule. Jean-Marc Moret contestou-a com firmeza, com argumentos imbatíveis.

Em face do objetivo do presente estudo, eu não poderia esquivar essa discussão. Mas o leitor talvez ache que fiz um trabalho contraproducente, comprometendo minha argumentação: afinal, eu tentava justificar meu apelo ao conceito de "fascinação" para explicar aspectos do mito de Édipo, postulando que o fascínio tem um componente erótico. Não deveria, portanto, apegar-me à tese de Delcourt?

Efetivamente contesto que haja, nas imagens apresentadas pela famosa helenista à guisa de testemunhos em prol de sua tese, qualquer indicação de ato sexual, de um coito entre o monstro da saga tebana e suas vítimas. Não vejo base alguma para a caracterização da esfinge como "íncuba". Mas isso não implica negar que exista um colorido erótico em cenas míticas que a envolvem.

Tudo depende, é claro, do que se entende por erótico. Segundo penso, não é legítimo restringir o conceito de tal modo que só se possa falar em erotismo (na arte, por exemplo) quando se trata de atos sexuais explícitos ou sugeridos de forma direta. Isto seria empobrecer muito a noção do erótico. Assim amesquinhada, ela ficaria bem distante do que os gregos chamavam de Éros. Mas eles não hesitariam em relacionar com esta potência cósmica, sagrada a seus olhos, o que chamei de "fascinação".

Na poesia, a esfinge era freqüentemente caracterizada como a "virgem alada". Em algumas variantes do mito de Édipo, dá-se-lhe a feição toda antropomorfa de uma guerreira, de uma pirata, ou de uma ladra ${ }^{19}$ : uma donzela "indômita" em quem a selvageria das virgens se exprimia de forma letal, tornando-a matadora de homens. Uma perversidade de amazona constitui, então, um seu traço característico - traço que a parthénos feroz não deixa de apresentar quando tem a sua caracterização teriomórfica mais comum.

Ora, aos olhos dos gregos a imagem de uma perigosa virago exprimia qualquer coisa de, ao mesmo tempo, terrível e sedutor. Nas amazonas - "mulheres indômitas", terríveis viragos - transparecia um encan- 
to sinistro. Um herói podia impor seu domínio sobre semelhante "monstro" pelo jugo do amor ou da morte: a conquista de Hipólita representou um feito ao mesmo tempo bélico e amoroso de Teseu.

A esfinge pirata da versão de Pausânias da história de Édipo, sua meia-irmã, foi vencida e subjugada por este herói. O periegeta não conta o que aconteceu depois: bastou-lhe dizer que o filho legítimo de Laio a dominou. Outras versões tardias do mesmo mito sugerem uma aliança do par, encerrada, porém, com o logro e a morte da mulher terrível ${ }^{20}$.

(Esta tradição não foi infecunda: nos contos do folclore grego moderno, Édipo desposa a Esfinge).

Voltando às variantes mais conhecidas, é tempo de chamar a atenção para um traço contraditório desse ser medonho, muito visível em numerosos documentos plásticos da Antiguidade: sua perturbadora beleza. Tratase de um monstro com feições de mulher bonita, que desafia os homens.

Bela, terrível, arrebatadora...

Há uma inversão do gámos no rapto de varões que a esfinge pratica.

Como se sabe, a liturgia grega do matrimônio prescrevia uma encenação do arrebato da noiva - da parthénos - pelo homem que a dominaria. Quando se fala em uma parthénos que persegue e subjuga homens, a sugestão erótica é ineludível, ainda que se acompanhe de uma nota sinistra assinalada pela inversão. No imaginário grego da morte, ela evoca o transe do gámos por causa do arrebato que sofre seu paciente, dominado, subjugado. A imagem do casamento como imposição do jugo, uma espécie de "doma" da parthénos, era familiar aos gregos. Os helenos efetivamente viam no rapto um símbolo adequado dos trabalhos de Éros e de Thánatos. O mito de Perséfone é o melhor testemunho neste sentido.

Impossível negar a presença de um elemento atrativo na figuração da esfinge, na sua aura mítica. Quem quisesse contestá-lo de modo absoluto logo se veria a braços com uma dificuldade muito grande. Pois se, na poesia, a esfinge é chamada constantemente de parthénos, por outro lado há sólidos testemunhos de que os antigos gregos apelidavam de "esfinges" as prostitutas. Ao fazê-lo, acentuavam duas coisas na caracterização da categoria visada: a graça sedutora com que essas "esfinges" ofereciam aos clientes um arrebato de gozo... e o poder de levá-los à ruína ${ }^{21}$.

Belas destruidoras...

É preciso fazer justiça ao caráter complexo da figura mítica da adversária de Édipo. A simplificação resulta mutiladora. A harpaxándra (título da esfinge, traduzível por "arrebatadora de varões") era caracterizada como parthénos, donzela; mas os gregos, conforme se viu, também achavam pertinente comparar-lhe a porné, a puta. 
Enquanto parthénos, a Esfinge exprime um furor que se liga ao bestial e ao sagrado. Recorde-se o quanto há de selvagem na Virgem Ártemis e no simbolismo de suas árktoi, na caracterização das pequenas donzelas da Braurônia ${ }^{22}$.

Os gregos antigos efetivamente enxergavam nas virgens qualquer coisa de ferino: consideravam a virgindade uma condição de certo modo próxima do demoníaco, aberta a suas manifestações; recorde-se que eram virgens as profetizas helênicas. A moça não "domada", não domesticada, teria consigo uma força julgada capaz de exprimir-se, em outro registro, como fúria sangrenta (recorde-se que Aquiles "foi" Pirra); mas a "doma", que converte essa disposição desumana e selvática da inupta na de mulher "feita", envolve o trabalho de Afrodite; portanto, é o potencial erótico da virgem que se revela em sua inclinação ferina, quase-demoníaca. Nessa perspectiva, a fêmea humana que se mantém virgem "desvia" da realização "normal" a potência erótica, rumo ao anormal-sagrado, quer na sua feição positiva, quer na negativa: pode levar ao vaticínio (como, por exemplo, no caso de Manto) ou ao furor (como no caso das Danaides).

Por outro lado, também a porné, a seu modo, escapa à domesticação do matrimônio; é também desviante, com relação ao rumo "certo" das núpcias. E sua promiscuidade pode interpretar-se como um traço bestial. O cômico Anaxilas fez sobressair na sua comparação [esfinge = porné] um traço significativo: a prostituta, conforme ele sugere, dedica-se a uma espécie de rapina, cujas vítimas são os varões (é uma harpaxandra). Pois bem: é impossível não advertir o elemento fascinante em uma rapina com sedução.

Mais uma coisa subentende-se no paralelo de Anaxilas: algo haverá na Esfinge do mito que corresponda ao poder de sedução da bela cortesã. Segundo penso, a iconografia revela o que vem a ser isso: manifesta-o quando atribui uma estranha beleza à Indagadora, destaca seu olhar fulminante e mostra o efeito em suas vítimas dessa mirada, tão enleadora quanto a pergunta que ela cifra.

O embaraço também pode conotar uma situação erótica: não por acaso falamos de enleio amoroso... Creio que até mesmo o processo da interpelação enigmática pode ser correlacionado metaforicamente com o campo do erotismo; não há de ser gratuito o fato de que em muitas sociedades os festejos pré-nupciais envolvem jogos de adivinhas e prendas, jogos com enigmas.

Marie Delcourt está certa quando chama a atenção para o fato de que a esfinge nunca é representada a assaltar mulheres; nunca se menciona uma sua vítima feminina (as harpias, por exemplo, também 
arrebatavam fêmeas). Isso traduz um aspecto importante do seu mito: a oposição masculino/feminino em termos de uma ligação contraditória. Na iconografia, a ferina mulher alada é vista, na maioria dos casos, a perseguir e a capturar moços, cuja aparência denuncia uma classe de idade específica: a faixa dos núbeis. Será apenas por que, como alega Moret, pretendia-se mostrá-la atacando Tebas no seu porvir, destruindo os seus futuros defensores? A explicação não convence. Tudo indica, ao contrário, que desde as primeiras raízes da saga tebana um componente erótico associa-se ao desempenho da Esfinge: os dois versos remanescentes da Edipodia rezam que ela arrebatou também "o mais belo e mais desejável de todos, o filho querido do irreprochável Creonte, o divino Hémon".

Delcourt evoca estes versos famosos a propósito de uma cena pintada em figuras negras num lécito do Cabinet des Medailles, 278 (1944:34 e CVA t. I, pl. 46, ns. 7, 8, 9), de circa 450, vaso encontrado em Cervetri, na Etrúria. Aí se vê uma esfinge perseguindo um jovem nu, que lhe foge a correr com a cabeça voltada para trás, mas é já alcançado pelas patas dianteiras do monstro. Apesar de sua posição de ataque, a esfinge tem um rosto sereno, bonito. Os olhos do fugitivo erguem-se para os seus, com uma expressão de temor; há uma certa candura na imagem dele. Flanqueando o par, de cada lado, assiste um personagem vestido, com um objeto à altura do ventre que parece ser um escudo. Não há nada que permita relacionar particularmente essa figura, de um modo direto, com o poema referido; também nada desautoriza a evocação que fez Delcourt ${ }^{23}$.

Que cenas de combate protagonizadas por personagens de sexos opostos possam ter conotações eróticas não é inacreditável. O leitor não precisa lembrar-se de Tasso e dos líricos árabes para admiti-lo; mantendo-se nos limites da Grécia Antiga, basta que se recorde da cena que celebrizou o pintor de Pentesiléia.

Em muitos dos testemunhos da pintura cerâmica, através do que chamei de "duelo visual" abre-se campo a um paralelo entre a situação mortífera em que a esfinge confronta os varões em um outro campo de sentido. Ela fascina, de modo que produz enleio e, em seguida, mata. Um olhar invasor desfecha-se sobre o outro e o sujeita; verte sua força no que o recebe, e assim o domina imprimindo-lhe sua intenção de morte. Esse movimento agônico, em que outra esfera se realiza assim, pelo mesmo processo de embeber os olhos?

Impossível negar que o fascínio mortal e o fascínio erótico se correspondem. Por certo não se equivalem; não digo que a mirada da esfinge, no que encontra e penetra a da vítima ou a faz abater-se, tenha uma cor lúbrica visível nas representações consideradas. Mas aponto uma corres- 
pondência que não se pode eludir. Noto ainda uma coisa: no jogo mortal, a fera fêmea tem um papel ativo: toma a iniciativa, cria o embaraço do admirado e nele inocula seu intento, ao contrário do que é comum (ou melhor, do que era "normal" para os gregos) na situação erótica do desfitarse de homem e mulher.

O (amoroso) olhar "fulminante" tem qualquer coisa de fálico e impõe ao olhar que o reflete um caráter sexual simétrico. Recorde-se, a propósito, um verso de John Updike: "Eyes are penises, mirrors are vaginas". Pois bem, olhos também são espelhos!

O ambíguo poder sexual dos olhos seria um fator decisivo da sua valência apotropaica. Inúmeros testemunhos da iconografia helena (em particular, da pintura cerâmica) comprovam o uso de figuras de olhos com esta função.

Documentos iconográficos também mostram que, na Antiguidade, o confronto ocular da esfinge com Édipo veio, em certas instâncias, a ser "traduzido" no código sexual, com apelo a um simbolismo também evocativo de procedimentos mágicos. Não diminui em nada a importância desses testemunhos o fato de que eles são poucos e correspondem a vasos flíacos ${ }^{24}$. Seu número reduzido não obsta a que se possa relacioná-los com uma tradição: a da sátira teatral. Se pouca coisa nos restou desta, ninguém se arriscará a negá-la; ninguém, em são juízo, afirmará que ela foi pobre.

Nas pinturas de vasos do gênero, o desenho caricatural visa de modo claro realizar uma paródia. Isto não significa resvalar para o gratuito, antes o contrário; a paródia só se efetiva se tiver algum fundamento. Não pode ser arbitrária, recorrer a paralelos inaceitáveis, a idéias que nenhum consenso autorize. Tem de mostrar-se verossímil. A deformação que faz segue um esquema simbólico, percorre o campo de uma analogia; se esta não for reconhecida, se o juízo do espectador não a estima pertinente, a caricatura falha, perde-se, não resulta em coisa alguma. O assunto deve prestar-se à sátira, e é o público quem decide. Ora, que o drama do confronto de Édipo com a Esfinge era passível de uma transcrição satírica, ninguém negará: Ésquilo, autor de um Édipo, também o foi de uma Sphynx Satyriké.

Entre o arrebato místico, o êxtase amoroso e a morte há ligações que a arte, em todos os tempos, sempre se empenhou em mostrar. Por outro lado, ainda falamos em "transportes" de amor e no "transe mortal". Pois bem: a esfinge é veículo do transporte imaginário do morto para o outro mundo em muitas representações antigas ${ }^{25}$. Sim, a esfinge é um dos símbolos do notável repertório grego ligado a uma erótica da morte. Também por isso suas representações tinham, freqüentemente, um valor apotropaico. A relação entre a esfinge e Édipo mostra que ele não é estranho a este campo de valor. 
A última tragédia sofocleana dá testemunho no mesmo sentido, quando associa o herói às Eumênides. Esta ligação nada tem de gratuito. Sabese que as Erínias de Laio e Édipo recebiam um culto especial, prestado por uma família nobre ${ }^{26}$ que assim queria garantir sua própria continuação, assegurar-se a ameaçada geração de filhos: por outras palavras, esse culto destinava-se a prevenir o perigo da esterilidade, apartá-lo, removê-lo. Édipo assim oferecia remédio contra o que provocou em Tebas.

E seu túmulo secreto era também (mas contra as armas tebanas) um apotrópaion.

Nas tragédias em geral, trata-se do destino inflexível, do que é propriamente átropos (irreversível, inelutável). Por outro lado, com muita freqüência, nelas se mostra um tipo de situação muito peculiar: de súplica, de prostropé. Assim começa, por exemplo, o drama sofocleano do Rei Édipo: trazidas pelo sacerdote de Zeus, crianças que têm nas mãos ramos de oliveira enrolados com fitas de lã assentam-se junto aos altares do soberano. Ele é o alvo da súplica, portanto é desde logo atingido por "uma potência terrível e que... atua automaticamente" (Gernet 1968:295-298): uma força ameaçadora, não raro terrível, quando recai sobre um sujeito humano. Esse tremendo poder constitui, sem dúvida, um motor da viragem ocorrida no drama, viragem em cujo termo o rei acaba por volver-se em um miserável suplicante. A possibilidade trágica da reviravolta assim operada, em que o propriamente átropos se manifesta, já abre caminho para que se inscreva no mesmo campo (dramático) uma outra transformação: aquela de que decorre, ou pode decorrer, a produção do apotropaico. É o que revela o ciclo sofocleano de Édipo. Basta isto para que se reconheça no conceito em apreço uma categoria do pensamento trágico.

Em todos os contextos onde essa idéia se mostra operativa, cabe relacionála com o sentimento do destino e com os valores opostos de pureza e impureza. Ninguém negará que esses elementos têm uma importância axial na cosmovisão religiosa dos gregos. É preciso, pois, deixar de lado o preconceito que cinge estreitamente ao campo da magia a idéia do apotropaico. 
Recebido em 07 de junho de 2005

Aprovado em 08 de julho de 2005

Ordep Serra é professor adjunto do Departamento de Antropologia da Universidade Federal da Bahia. E-mail: <ordepserra@terra.com.br>

\section{Notas}

${ }^{1}$ Reporto-me a uma longa fala de Édipo, entre os versos 771 e 833. Destaco o trecho que vai do verso 813 ao 829. A hipótese do daímon cruel é formulada nos versos 828 e 829 do Oidipous Rex. Todas as citações de Rei Édipo neste trabalho remetem à minha tradução (Serra 2004).

${ }^{2}$ Cf. Oed. Rex, vv. 1252-1279, e em especial o verso 1258.

${ }^{3}$ Oed. Rex, v. 276: "Ó rei, como obriga a praga do teu conjuro, respondo...".

${ }^{4}$ A propósito, recorde-se que, em grego, não havendo um designativo específico do suicídio, usa-se, neste caso, os termos cunhados para indicar o parricídio: ao matar Laio, Édipo comete, na perspectiva da cultura helênica, um ato "suicida". A respeito, veja-se Nicole Loraux (1988:30 e nota 12, ao final).

${ }^{5}$ Mas há notáveis exceções. Os versos 677-679 do Canto XXIII da Ilíada falam dos jogos fúnebres de Édipo em Tebas. A famosa passagem da Odisséia XI:271-280 diz explicitamente que ele continuou a reinar em Tebas depois da revelação do incesto e do suicídio de sua mãe.

${ }^{6}$ Viragem é o termo que uso para designar o mesmo que renversements, reversal, tropé. Sigo o procedimento de Eudoro de Sousa (1978) na sua tradução de Heráclito.

${ }^{7}$ Assim, por exemplo, seu gesto de legítima defesa acaba por ser um parricídio, e seu casamento glorioso, prêmio de uma grande façanha, resulta em incesto.

${ }^{8}$ O sangue (derramado) de parentes, de consangüíneos: o sangue de Laio, seu pai, que Édipo matou.

${ }^{9}$ A propósito, veja-se Vidal-Nacquet (1991:183-220 e, especialmente, pp. 200-214).

${ }^{10}$ Como mostrou Vidal-Nacquet (1991). 
${ }^{11}$ Loxias é um título de Apolo que se pode traduzir por "Oblíquo"; faz referência ao arrevesado dos oráculos.

${ }^{12}$ Reporto-me aos versos 113-115 de Rei Édipo: ... "Mas se com esse estranho/ Laio tem de comum a natureza/ Qual dos homens será mais infeliz do que eu?" Notese a ironia trágica.

${ }^{13}$ Eis a glosa: "Fascinum [fascínio], que em grego se diz baskanía, é um tipo de feitiço pelo qual os homens ficam de tal modo enleados que perdem a liberdade e o controle de sua mente e, muitas vezes, ficam depauperados, reduzidos a magreza extrema [...] Por extensão, dá-se este nome à imagem do falo, porque os antigos empregavam o falo contra a fascinação. Pois falos erigidos desviam e afastam as torpezas dos olhos maus dos invejosos. Assim como se acreditava que aves de mau agouro pregadas nas portas quebram a força do azar, acreditava-se também que os falos, costumeiramente usados em feitiços, repeliriam os mesmos".

${ }^{14}$ De um modo geral, nos documentos da pintura cerâmica onde se encontra tematizado o motivo do assalto da Esfinge aos tebanos, três informações destacam-se, veiculadas separadamente ou em conjunto: (a) a que diz respeito ao processo da interpelação mortífera; (b) a que concerne à difusão da notícia do desafio da Esfinge, e do pânico que a novidade acarreta; (c) a que concerne ao enleamento de uma vítima estupefata, tolhida de um jeito fúnebre, os olhos arregalados de horror em face do olhar penetrante da Esfinge.

15 Dá-se ainda uma outra variação: Ingrid Krauskopf [1981:12 (LIMC, s.v. Oidipous)] chama a atenção para a cena representada pelo Pintor de Aquiles em uma pélike do Museu de Berlim (F 2355), de 450/440 a.C. (cf. Moret 1984:79, pl. 46/1), "em que ambos, tanto a Esfinge como Édipo, olham para o chão melancolicamente, como se já previssem seu infortúnio por vir".

${ }^{16}$ Por exemplo, em uma taça de Siana de Siracusa, n. 25.418, pintada em figuras negras, datável de 570/560 a. C. Aí se vê representada uma esfinge de rosto juvenil, cabelos longos, asas paralelas a prumo, a perseguir um grupo de oito jovens desnudos que correm em uma pose estereotipada. O elemento mais interessante da composição é a figura de um jovem que parece prender-se à esfinge, com o corpo colado ao seu: o braço visível desse rapaz adere à asa da fera e suas pernas surgem pendentes entres as coxas dela (sem que os pés do agarrado toquem o solo). Delcourt (1944:120) liquidou o assunto em uma única frase, como quem aponta o óbvio: "O artista aí representou um symplegma [um enlace] do modo o mais claro possível". Mas como observa Moret, aí não há como pensar em união sexual pois "os pintores de vasos, que representaram com um realismo às vezes tremendo as cópulas mais estranhas, neste caso se limitam a um enlaçar o mais neutro possível". Além disso, há outras coisas. Primeiro, observarei que a Esfinge, na cena em apreço, está visivelmente a correr atrás de um pelotão de rapazes. Mesmo para um monstro mitológico, é demais; haverá demônio que persiga oito enquanto copula com um? A hipótese da convenção impõe-se. Creio que o pintor quis dizer: "um já foi capturado; há muitos outros sob ameaça". (A primeira vítima é "assunto liquidado"). Quanto à interpretação delcourtiana, não param aí as dificuldades... A mestra escreveu também que o efebo volta os olhos para 
o rosto da Esfinge, porém isso não é exato: seu olhar parado perde-se, no máximo, na altura do pescoço da captora. A posição do "casal" também não me parece convincente em termos de indicação de um enlace, mesmo mitológico: os pés do moço pendem no ar. Para supor uma situação de míxis com um mínimo de verossimilhança, seria preciso crer que o jovem lânguido crava as unhas com firmeza nas asas da Esfinge, que ela tem o sexo um tanto "deslocado" e que ele sofre de penis captivum. Mas a posição do rapaz relativamente ao monstro é de todo insólita, não segue um modelo natural. Isto quer dizer que o "pintor C", ao construir esta imagem, estava conscientemente a valer-se de uma abstração, com o objetivo de representar coisa diversa do que Delcourt imaginou. Ele segue um esquema, traça uma espécie de metáfora visual.

${ }^{17}$ A saber: (1) o lécito do Louvre CA. 111 (L 28), pintado em figuras negras sobre fundo branco, datável de circa 480 (composição do Pintor de Hémon); (2) o lécito de Siracusa (12805), proveniente da tumba 891 de Mégara Hibléia, pintado em figuras negras sobre fundo branco (composição do pintor de Hémon); (3) o lécito de Atenas 12954 (N 965), pintado em figuras negras sobre fundo branco (composição do Pintor de Hémon); (4) o lécito de Viena 190, pintado em figuras negras sobre fundo branco, datável de circa 480 (composição do pintor de Hémon); (5) o lécito de Manheim (128), de figuras negras sobre fundo branco, datável de circa 470 (composição do Pintor do Empórion); (6) o lécito de Princeton 57, pintado em figuras negras sobre fundo branco, datável de circa 470 (composição do Pintor do Empórion).

${ }^{18}$ Nos lécitos do Pintor do Empórion que Delcourt relacionou em apoio de sua tese, acha-se também um mesmo esquema figurativo: em todos eles, um embate entre uma esfinge e um efebo parece ser testemunhado por transeuntes. A mitóloga estimou que esse embate seria amoroso, mas nada o confirma nas figuras. A propósito, ver Serra 1997.

${ }^{19}$ Ela é pirata na versão de Pausânias, IX, 26, 2-3. Palaífato (De incredib. 7), tentando racionalizar a legenda, produziu uma versão interessante da mesma: a Esfinge seria uma antiga mulher de Cadmo, que este herói abandonou quando se casou com Harmonia. A amazona enciumada formou um bando e refugiou-se na montanha, de onde arremetia contra os tebanos, armando-lhes emboscadas. Palaífato lembra que em grego ainígma significa também tocaia, emboscada — e explica assim um intrigante elemento da história tradicional.

${ }^{20}$ Nas versões de George Cedrênio e de João Malalas; cf. Carl Robert (1915: I:502 e II:169).

${ }^{21}$ É o que mostra o fragmento do cômico Anaxilas, citado em Ateneu XIII 558a-e.

${ }^{22}$ Brauron, na Ática oriental, uma das cidades incorporadas no sinecismo atribuído a Teseu, celebrizou-se pelo seu culto a Ártemis, em cuja honra aí se celebrava atualmente a festa chamada de Braurônia; nessa festa, meninas de cinco a dez anos, vestidas em túnicas cor de açafrão, imitavam ursas (árktoi). Na época clássica, essa festa passou a integrar o culto estatal de Atenas.

${ }^{23}$ Outros estudiosos lembram-se melhor de Hémon à vista de figurações em 
que um jovem guerreiro dá combate à bela fera. Pode-se pensar nele, por exemplo, contemplando uma gema em calcedônia de começos do século V (Vermeule 1984:286, fig. 24) em que uma esfinge salta sobre um homem nu, lacerando-lhe o peito com a garra dianteira visível. Caindo embora, o guerreiro resiste: empunha na mão direita uma espada e contrai os músculos de forma que torna evidente sua disposição de golpear. A esfinge tem uma expressão de serenidade quase prazenteira.

${ }^{24}$ Evocarei primeiro a pintura de um vaso muito interessante: a enócoa de Boston 01.8036, peça de provável origem campânia, quiçá do terceiro quartel do sec. IV. [Krauskopf 1981 (LIMC 710); Moret 1984 cat. 194, pl. 95]. Vê-se aí, no alto do que parece uma coluna retorcida (ou uma inverossímil formação rochosa), com uma serpente com jeito de "incrustada" no trecho (ou bloco) mais elevado, uma pequena esfinge agachada, com seios de mulher empinados, cabelos curtos, rosto de garoto adolescente. Seu corpo nu é quase inteiramente antropomorfo, à exceção das patas e das asas recolhidas (quase se tocam atrás). No centro, um arbusto medeia entre a penha da Esfinge e o outro personagem dessa representação: um jovem esquálido, tão magro quanto a figura que confronta. Trata-se de Édipo, sem dúvida. O herói, que tem na cabeça um pîlos, parece desnudar-se: sua mão esquerda prende na cintura uma ponta de um manto, que do outro lado cai sobre o cajado; ele apóia a destra neste bastão, no qual se escora - e torna bem visível um grande falo flácido, para o qual se volta o olhar perplexo da Esfinge. Tudo sugere a realização eficaz de um gesto apotropaico, assinalada de forma cômica. Considere-se também a cena representada em uma enócoa ápula de Tarento de 370/360 a. C. da col. Ragusa, n. 74 [Krauskopf 1981 (LIMC s.v Oidipus) cat. 70; Moret 1984 cat. 193, pl. 94], em um estilo que se associa ao do Pintor de Felton. A Esfinge, de seios flácidos, rosto grotesco de velha megera, equilibra-se em um extravagante rochedo tortuoso que se inclina para a esquerda de um modo inverossímil. Tem asas que lhe deixam a cabeça "entre parênteses", patas de predador, e um longo rabo. Este se entorta e aparentemente se bifurca perto da extremidade, projetando um falo infibulado. No resto do corpo, essa figura é antropomorfa. O que a torna mais chocante é que ela está nua e deixa em plena evidência sua grande vagina. À frente da Esfinge, mais abaixo, assenta-se em uma penha ou banco de pedra um velho barbudo, de calva pronunciada, com um bastão sob um dos braços. A túnica pendente do ombro esquerdo deixa-lhe o tronco nu, mas cobre-lhe o resto do corpo, da cintura para baixo, quase até os pés. Este personagem, que bem pode ser Creonte, volta-se, com um braço um pouco levantado, para um jovem atrás de si, com quem tudo indica que está a discutir. É fácil reconhecer Édipo no moço de feições grotescas que gesticula de forma um tanto exagerada, como se apontasse a Esfinge e argumentasse com o ancião: ele tem enormes pés inchados. Esta pintura decerto relacionava-se com algum drama satírico. Dá para imaginar o entrecho: Édipo barganharia com Creonte, procurando obter o máximo de vantagens antes de propor a solução do problema. O que mais chama a atenção é o acúmulo dos signos sexuais na figura da Esfinge. Mas não é só isso que surpreende: Édipo acha-se representado aí, de maneira insólita, com seu estigma muito evidente, talvez para indicar o poder fálico, penhor da vitória do herói. Convém agora trazer à baila a pintura de uma pequena taça coríntia de Oxford, de uma coleção privada (integra o Sam Wide Group), exposta no Ashmolean Museum [cf. Krauskopf 1981:69 (LIMC Oedipus); Moret 1984, cat. 195). Ela dataria, talvez, do último terço do século V. Nesta peça, quase todo o espaço da representação 
é dominado pelo monstro sobre a coluna. Os franceses podem dizer tanto le Sphynx como la Sphynx; em português, infelizmente, não temos a mesma liberdade... O monstro, no caso, vem a ser uma Esfinge-macho, de corpo miúdo, mirrado, bem menor que as asas, porém de cabeça enorme, ainda mais desproporcional, embora a supere em desproporção o falo desmesurado do mesmo ente. O monstro masturba-se, e ejacula; o jato de esperma está para cair sobre um jovem (sem dúvida Édipo) que, junto à coluna, cabeça à altura do capitel, olha para o alto e protege-se com a clâmide (vê-se-lhe às costas o pétasos preso ao colo). Ao tempo em que se defende, o herói com ar de garoto prepara o contrataque: vê-se o seu gládio ereto, mostrado com uma forma e em uma posição que se podem qualificar de "fálicas". Apesar disso, o Édipo assim caricaturado tem um quê de feminino, de andrógino, em seu rosto imberbe muito pueril. Já quanto ao monstro, segundo comenta Moret (1984:144), "masculinidade, natureza fálica e agressividade se combinam nesta inversão do ideal heróico, que neste caso quem manifesta é o Esfinge". A iconografia oferece exemplo de Esfinge com falo: veja-se a urna de alabastro de Volterra 355 [Krauskopf 1981 (LIMC Oidipous 58a); Moret 1984, cat. 111, pl. 70/1], datável do século III, onde se reconhece logo a fera da saga tebana em confronto com Édipo. Nesta obra etrusca, o monstro tem corpo de centauro e pisa sobre restos humanos, mas seu semblante é feminino. Já na taça coríntia de que agora se trata, o atributo fálico soma-se a uma série de traços que conferem ao estranho ser uma expressão em tudo masculina e agressiva. Moret observa (1984:144-145) que a caricatura no vaso coríntio "em lugar do enunciado verbal [do enunciado do enigma, quer dizer] mostra a emissão seminal...". Mas do mesmo jeito pode-se dizer que a violência da ejaculação a ameaçar Édipo, de um lado, e o ataque por ele preparado com seu gládio "fálico", de outro, traduzem o agón insinuado, em muitas representações, pelo confronto dos olhares. O gesto do monstro caricato, sem dúvida, pode ainda ser considerado apotropaico, segundo Moret sugere (1984:145, nota 2): caberia presumir que Édipo decifrou o enigma, ou de algum modo se mostrou capaz de vencer o desafio, de modo que o seu adversário se refugiou no gesto onanista, talvez como um último recurso mágico, talvez em uma desesperada compensação.

${ }^{25}$ Por exemplo, no já citado lécito de Atenas 1607; na pintura de uma taça do pintor de Evergides, quiçá do último decênio do século VI, recomposta através de fragmentos do Louvre (Cp. 11.224) e de New York (1076.20.1); nas imagens do fragmento de uma hídria de 480, obra do pintor de Eucárides (Frgt. de Innsbruck II, 12, 333. Hídria em figuras vermelhas (Cf. Moret 1984, cat. 24, pl. 15/3); nas do lécito de Kiel B 555 (circa 470).

${ }^{26}$ O génos dos Egeidas; cf. Herod. IV, 147-149. 


\section{Referências bibliográficas}

BEAZLEY, John D. 1956. Attic black-figure vase painters. Oxford: Oxford University Press.

BOISACQ, Émile. 1923. Dictionnaire étymologique de la langue grecque étudiée dans ses rapports avec les autres langues indo-européennes. Paris: Librairie Klincksieck.

CVA - Corpus vasorum antiquorum. 2002-2004. Union Académique Nationale/ Beazley Archive. http:// www.cvaonline.org/cva/ProjectPages/ CVA3.htm

DELCOURT, Marie. 1944. Oedipe ou la légende du conquérant. Liège: Bibliothèque de la Faculté de Philosophie et Lettres de l'Université de Liège.

FOUCAULT, Michel. 1971. A verdade e as formas jurídicas. Rio de Janeiro: PUCRio, Departamento de Letras e Artes. FORCELLINI, Egidio. 1771. Totius latinitatis lexicon, consilio et cura. J. Facciolati, opera et studio Aegidii Forcellini alumni seminarii Patavini, lucubratum, 4 vol., Patavii.

FURTWÄNGLER, Adolph. 1900. Die antike gemmen. I-III. Berlim: Akademie Verlag.

GERNET, Louis. 1968. Anthropologie de la Grèce Antique. Paris: Maspéro.

GREEN, André. 1994. O desligamento. Rio de Janeiro: Imago.

HÖFER, Otto 1902. "Oidipus". In: W. H. Roscher (org.), Aufürliches lexikon der griechischen und römischen mythologie III (I). Leipzig: Georg Olms. pp. 700-746.

LÉVI-STRAUSS, Claude. 1967. Antropologia estrutural. Rio de Janeiro: Tempo Brasileiro.

.1976. Antropologia estrutural II. Rio de Janeiro: Tempo Brasileiro.
1984. Paroles données. Paris: Plon. KRAUSKOPF, Ingrid. 1994. "Oidipous". In: N. Yalouris et alii (orgs.), Lexicon iconographicum mythologiae classicae. Zurich/ München: Artemis Verlag. vol. VII, pp.1-15.

LLOYD-JONES, H. \& WILSON, N. G. (eds.). Sophoclis Fabulae. Oxford University Press, 1990.

LORAUX, Nicole. 1988. Maneiras trágicas de matar uma mulher. Rio de Janeiro: Jorge Zahar Editor.

MORET, Jean-Marc. 1984. Oedipe, la sphynx et les thébains. Essai de mythologie iconographique. Bibliotheca Helvetica Romana. Genève: Institut Suisse de Rome.

ROBERT, Carl. 1915. Oidipous. Geschichte eines poetischen stoffs im griechischen Altertum. Berlin: Weidman.

SERRA, Ordep. 1997. O reinado de Édipo. Tese de Doutorado, Universidade de São Paulo. 2002. Veredas. Antropologia infernal. Salvador: EdUFBA. .2004. Sófocles. Rei Édipo. São Paulo: Editora Peixoto Neto.

SIMON, Erika. 1981. "Das satyrspiels sphynx des aischyllos". Sitzungsberichte der Heidelberg Akademie der Wissenschaft, 5:7-41.

SOUSA, Eudoro de. 1978. Filosofia grega. Brasília: Editora da Universidade de Brasília.

VERMEULE, Émile. 1984. La muerte en la poesia y en el arte de Grecia. México: Fondo de Cultura Económica.

VERNANT, Jean-Pierre. 1981. "Ambiguité et renversement. Sur la structure énigmatique d'Oedipe-Roi". In: J. P. Vernant e P. Vidal-Nacquet (orgs.), Mythe et tragédie en Grèce Ancienne. Paris: Maspéro. pp. 100-131. 
. 1991. "O tirano coxo: de Édipo a Periandro". In: J. P. Vernant e P. VidalNacquet (orgs.), Mito e tragédia na Grécia Antiga II. São Paulo: Brasiliense. pp. 47-76.

VIDAL-NACQUET, Pierre. 1991. “Édipo entre duas cidades. Ensaio sobre o 'Édipo em Colono'". In: J. P. Vernant e P. Vidal-Nacquet (orgs.), Mito e tragédia na Grécia Antiga II. São Paulo: Brasiliense. pp.157-182. 


\section{Resumo}

Focalizando as tragédias sofocleanas Rei Édipo e Édipo em Colono, mas considerando também outras versões e documentos iconográficos relativos ao mito de Édipo, busca-se evidenciar que a noção do apotropaico desempenha, nesse contexto, um papel significativo. Sugere-se que as crenças e as práticas nas quais este valor se exprime têm raízes no plano mais profundo de uma cosmovisão tradicional dos helenos: têm a ver com idéias sobre o destino e com categorias fundamentais do pensamento religioso dos gregos. Sustenta-se que o código do apotropaico tem na magia (domínio ao qual inúmeros estudos tendem a cingi-lo), apenas uma de suas expressões, cuja interpretação depende da análise de outros discursos da cultura grega. Na encenação da história de Édipo, a tragédia evidencia com singular clareza o sentido mais profundo do apotropaico.

Palavras-chave: Apotropaico, Édipo, Mito, Tragédia, Esfinge

\section{Abstract}

Focusing mainly on the Sophoclean tragedies Oedipus Rex and Oedipus at Colonnus, but also considering otherversions of the Oedipus myth and some of the iconographic documents relating to it, this article looks to show that the apotropaic element plays an important role in this mythic context. It suggests that the beliefs and practices through which the apotropaic value is expressed are rooted in the deepest grounds of the Greek Weltanschauung and related to conceptions of fate and the basic categories of Greek religious thought. Although many studies usually restrict its operation to this circle, the article argues that magic is just one of the fields in which the apotropaic code is expressed, and that the interpretation of this code requires the consideration of other discourses and the analysis of other aspects of Greek culture. In theatrical presentations of the Oedipus tale, the tragedy reveals the deepest meaning of the apotropaic with singular clarity.

Key words: Apotropaic, Oedipus, Myth, Tragedy, Sphinx 